\title{
PENINGKATAN KEPERCAYAAN DIRI DAN PROSES BELAJAR MATEMATIKA MENGGUNAKAN PENDEKATAN REALISTIK PADA SISWA SEKOLAH DASAR
}

\section{IMPROVING SELF CONFIDENCE AND MATHEMATIC LEARNING ACHIEVEMENT USING REALISTIC APPROACH IN STUDENTS OF PUBLIC ELEMENTARY SCHOOL}

\author{
Chrisnaji Banindra Yudha, Suwarjo \\ STKIP Kusuma Negara Jakarta Timur, Universitas Negeri Yogyakrta \\ chrisnajy@gmail.com, suwarjoraharjo@yahoo.com
}

\begin{abstract}
Abstrak
Penelitian ini bertujuan untuk meningkatkan kepercayaan diri dan proses belajar matematika siswa menggunakan Pendekatan Matematika Realistik (PMR) di kelas V SD N Semaken Kecamatan Kalibawang Kabupaten Kulon Progo. Penelitian ini adalah penelitian tindakan kelas (classroom action research) secara kolaboratif. Hasil penelitian menunjukkan bahwa PMR dengan tahapan (a) pemahaman masalah kontekstual, (b) mendeskripsikan dan menyelesaikan masalah kontekstual, (c) membandingkan dan mendiskusikan jawaban, dan (d) penarikan kesimpulan dapat meningkatkan kepercayaan diri dan proses belajar siswa. Peningkatan kepercayaan diri siswa dapat dilihat dari sebelum dilaksanakan tindakan. Terdapat 3 siswa atau $15 \%$ memunyai kepercayaan diri yang tinggi dan 17 siswa atau $85 \%$ memiliki kepercayan diri yang rendah. Selanjutnya pada siklus I sebanyak 14 siswa atau sebesar $70 \%$ memunyai kepercayaan diri yang tinggi dan 6 siswa atau sebesar 30\% memiliki kepercayaan diri rendah. Setelah penelitian dilanjutkan pada siklus II, sebanyak 18 siswa atau sebesar 90\% memunyai kepercayaan diri yang tinggi dan hanya 2 siswa atau sebesar $10 \%$ yang memiliki kepercayaan diri yang rendah. Peningkatan proses belajar ditunjukkan bahwa, dari sebelum tindakan didominasi guru dan setelah diterapkan tindakan didominasi siswa. Dari peningkatan proses belajar berakibat pada peningkatan hasil belajar. Pada siklus I sebanyak 17 siswa atau sebesar 85\% telah memenuhi KKM dan 3 siswa atau sebesar 15\% belum memenuhi KKM. Setelah dilakukan perbaikan proses belajar siswa pada siklus II, siswa yang memiliki nilai rendah (belum memenuhi KKM) mengalami peningkatan hasil belajarnya. Pada siklus II, jumlah siswa yang memenuhi KKM sebanyak 20 siswa atau $100 \%$.
\end{abstract}

Kata kunci: PMR, Kepercayaan Diri, dan Proses Belajar

\section{Abstract}

This study aims to increase self confidence and student learning achievement using Mathematical Realistic Approach (RME) in class V SD N Semaken District Kalibawang Kulon Progo Regency.This research is a classroom action research in a collaborative manner. The results show that Realistic Mathematical Approach (PMR) consistsing of the stages of (a) understanding contextual problems, $(b)$ describing and solving contextual problems, (c) comparing and discussing the answers, and (d) drawing a conclusion, can increase self-confidence and learning achievement of the students. Students increased self confidencecan be seenfrom thepre-executed action.There are 3 students or 15\% have high confidence and 17 students or $85 \%$ havelow self confidence. The increase of students self confidence can be seen in Cycle I. A total of 14 students or as much as 70\% have high self confidence and 6 students or 30\% have low self confidence. After extended research on Cycle II, a total of 18 students or as much as $90 \%$ have high self confidence and only 2 or as much as $10 \%$ of students have low self confidence. Indicated that an increase in the learning process, from teacher centered action before and after the applied measures student centered.improved of learning process in increased learning outcomes. The improvement of students learning avhievement can be seen in Cycle I. A total of 17 students or $85 \%$ have met the MML (Minimal Mastery Learning) and 3 students or 15\% have not met the MML. After efforts to improve students learning achievement in Cycle II, students who have low scores (do not meet MML) have increased their learing achievement. In Cycle II, the number of students who meet the MML is 20 students or $100 \%$.

Keywords: RME, Self Confidence, and Learning Achievement 


\section{Pendahuluan}

Mata pelajaran matematika di sekolah sangat penting untuk melatih pola pikir siswa. Matematika membentuk pola pikir yang memelajarinya khususnya siswa, diantaranya berpikir logis, analitis, sistematis, kritis dengan penuh kecermatan. Pembentukan pola pikir tesebut dapat diterima oleh siswa dengan baik apabila pembelajaran matematika di sekolah dikemas secara sistematis. Mengingat hal tersebut, maka diperlukan kemampuan kreativitas dan profesionalisme guru dalam memberikan pembelajaran matematika.

Menurut Ibrahim (2012, p.5), "Matematika adalah ilmu tentang pola dan hubungan, sebab dalam matematika sering dicari keseragaman seperti keterurutan, dan keterkaitan pola dari sekumpulan konsep-konsep tertentu atau model-model yang merupakan representasinya, sehingga dapat dibuat generalisasinya untuk selanjutnya dibuktikan kebenarannya secara deduktif." Dalam memahami konsep matematika dibutuhkan analisa yang mendalam dari pada ilmu yang lain dan siswa sering mengalami dan menemui kesulitan. Guru yang menyampaikan pelajaran matematika menganggap bahwa siswa dapat mengikuti jalan pikirannya dan memahami konsep dalam matematika seperti yang dipahami oleh guru tersebut. Logika berpikir guru beranggapan bahwa hal yang mudah, tetapi belum tentu mudah oleh pola berpikir siswa. Pada kenyataannya, siswa menganggap matematika sebagai pelajaran yang sulit untuk dimengerti. Anggapan yang semacam ini akan terus menerus menjadi momok bagi setiap siswa sampai generasi berikutnya. Oleh karena itu, peran guru sangat penting untuk membangun keyakinan siswa terhadap matematika khususnya di sekolah dasar.

Pada dasarnya manusia memunyai sifat ingin tahu. Sifat ini penting dalam proses perkembangan anak. Karena dengan sifat ingin tahu inilah orang berusaha untuk memeroleh sesuatu yang belum diketahui. Salah satu cara untuk mengetahuinya yaitu dengan cara belajar. Dari uraian belajar dalam pengertian belajar di atas, intinya adalah melalui belajar siswa atau orang dapat berubah tingkah lakunya.

Belajar matematika adalah suatu aktivitas mental untuk memahami arti dan hubungan-hubungan serta simbol-simbol, kemudian diterapkannya pada situasi nyata (Uno, 2009, p.130). Menurut pendapat Schonfeld (Uno, 2009. p.130), mengungkapkan bahwa belajar matematika berkaitan dengan apa dan bagaimana menggunakannya dalam membuat keputusan untuk memecahkan masalah.

Pembelajaran matematika memiliki 5 karakteristik menurut Gravemeijer (Zulkardi, 2002, p.2) diantaranya: (1) Penggunaan konteks: proses pembelajaran diawali dengan keterlibatan siswa dalam masalah kontekstual; (2) Instrumen vertikal: konsep atau ide matematika direkonstruksi oleh siswa melalui modelmodel instrumen vertikal, yang bergerak dari prosedur informal ke bentuk formal; (3) Kontribusi siswa: siswa aktif mengkontruksi sendiri bahan-bahan matematika berdasarkan fasilitas dengan lingkungan belajar yang disediakan guru, secara aktif menyelesaikan soal dengan cara masing-masing. (4) Kegiatan interaktif: kegiatan belajar bersifat interaktif, yang memungkinkan terjadi komunikasi dan negosiasi antarsiswa. (5) Keterkaitan topik: pembelajaran suatu bahan matematika terkait dengan berbagai topik matematika terintegrasi.

Gravemeijer (1994, p.66), menyatakan bahwa according to constructivist, every individual will try to build a theory of reality that is acceptable to him or her, and children try this as well. Dengan kata lain, pembelajaran berdasarkan paham konstruktivisme berarti siswa membangun sendiri konsep atau struktur materi yang dipelajarinya, siswa tidak lagi menerima konsep atau aturan yang telah dikemas oleh guru.

Dari pendapat di atas dapat disimpulkan bahwa pembelajaran matematika dapat bermakna apabila siswa yang menemukan sendiri konsep yang telah dipelajari. Belajar matematika siswa memahami tentang konsep-konsep dan prinsip-prinsip yang abstrak dan disusun secara hierarkis. Hal tersebut dapat dikuasai dengan mencoba dan memerbanyak latihan dalam mengembangkan ilmu matematika. Dalam belajar matematika harus mencoba mengembangkan penemuan. Penemuan tersebut harus ditemukan siswa melalui proses belajarnya.

Menurut (Hamalik, 2005, p.31), proses belajar ialah pengalaman, berbuat, mereaksi, dan melampaui (under going). Menurut Yamin, (2007, p.59), proses belajar mengajar merupakan proses yang sistematik, artinya proses yang dilakukan oleh guru dan siswa di tempat belajar dengan melibatkan sub-sub, bagian, komponenkomponen atau unsur-unsur yang saling berinteraksi untuk mencapai suatu tujuan. Menurut (Uno, 2009, p.54), sesuai dengan 4 pilar UNESCO, dalam proses pembelajaran diperlu- 
kan sebagai berikut: (a) Learning to know, yaitu peserta didik akan dapat memahami dan menghayati bagaimana suatu pengetahuan dapat diperoleh dari fenomena yang terdapat dalam lingkungannya; (b) Learning to do, yaitu menerapkan suatu upaya agar peserta didik menghayati proses belajar dengan melakukan sesuatu yang bermakna; (c) Learning to be, yaitu proses pembelajaran yang memungkinkan lahirnya manusia terdidik yang mandiri; (d) Learning to life together, yaitu pendekatan melalui penerapan paradigma ilmu pengetahuan, seperti pendekatan menemukan dan pendekatan menyelidik akan memungkinkan peserta didik menemukan kebahagiaan dalam belajar.

Dari uraian di atas, dapat dilihat bahwa siswa belajar akibat interaksi aktif dengan lingkungan. Dengan demikian dapat disimpulkan bahwa proses pembelajaran matematika adalah suatu proses yang dikelola sedemikian rupa sehingga siswa dapat belajar matematika. Siswa belajar matematika berarti dalam diri siswa berlangsung aktivitas mental/psikis secara aktif dengan lingkungan tersebut, sehingga dalam diri siswa terjadi perubahan-perubahan dalam bentuk pengetahuan, pemahaman, keterampilan dan nilai berkenaan dengan bagian matematika yang termuat dalam matematika sekolah.

Dalam hal ini ditekankan aktivitas yang berlangsung secara interaktif antara faktor intern pada diri siswa dengan faktor ekstern atau lingkungan, sehingga melahirkan perubahan dalam diri siswa. Dengan demikian dalam pembelajaran matematika diperlukan keahlian guru dalam usaha menciptakan kondisi pembelajaran yang dimulai dari isu-isu yang relevan dengan lingkungan.

Menurut Sudjana (2011, p.56), Pendidikan dan pengajaran dikatakan berhasil apabila perubahan-perubahan yang tampak pada siswa harus merupakan suatu akibat dari proses belajar yang dialaminya, Selanjutnya Apa yang dicapai siswa merupakan akibat dari proses belajar yang telah ditempuh siswa. Melalui kegiatan yang dilaksanakan bersama guru. Oleh karena itu, proses belajar yang maksimal cenderung menunjukkan hasil yang maksimal.

Dapat disimpulkan bahwa proses belajar dan hasil belajar merupakan saling berkaitan satu sama lain sebab hasil merupakan akibat. Dari kesimpulan ini pada penelitian yang dilaksanakan, sebagai akibat dari proses belajar meggunakan PMR sehingga diukur hasil belajarnya. Pengukuran hasil belajar dapat dilakukan de- ngan menggunakan alat evaluasi yang baik dan memenuhi syarat yang dilakukan oleh guru mata pelajaran. Hasil belajar penting untuk diketahui guna melihat tingkat penguasaan siswa terhadap proses pemberian materi yang diajarkan oleh guru dan dipelajari oleh siswa.

Menurut Sudjana (2010, p.5), penilaian proses dan hasil belajar dapat ditingkatkan melalui teknik tes dan non-tes. Teknik tes dapat berupa tes tertulis, tes lisan, dan tes praktik atau tes kinerja. Teknik non-tes dapat berupa observasi penugasan perorangan atau kelompok, angket, dan bentuk lain yang sesuai dengan karakteristik kompetensi dan tingkat perkembangan peserta didik.

Menurut Azwar (2011, pp.18-21), prinsip dasar tes hasil belajar adalah: (1) Tes harus mengukur hasil belajar telah dibatasi secara jelas sesuai dengan tujuan instruksional; (2) Tes hendaknya mengukur suatu sampel yang representatif dari hasil belajar, dan dari materi yang dicakup oleh program instruksional atau pengajaran; (3) Tes hendaknya memuat butirbutir atau item-item dengan tipe yang paling cocok guna mengukur hasil belajar yang diinginkan; (4) Tes hendaknya dirancang sedemikian rupa sesuai dengan tujuan penggunaan hasilnya; (5) Tes hendaknya diusahakan setinggi mungkin dan hasil skornya ditafsirkan secara cermat; (6) Tes hendaknya dapat digunakan untuk memerbaiki dan meningkatkan belajar siswa.

Berdasarkan pendapat di atas dapat diambil kesimpulan bahwa cara mengukur hasil belajar dapat digunakan dengan dua cara yaitu teknik tes dan non-tes. Tes digunakan untuk mengumpulkan data belajar matematika siswa. Tes diarahkan untuk penggalian informasi yang bervariasi dan berorientasi tingkat berfikir yang lebih tinggi. Objek belajar matematika yang luas membutuhkan tes yang terbuka dan memberikan kesempatan yang lebih luas bagi siswa yang menunjukkan bagian kompetensi matematis yang telah dan belum dikuasai siswa. Pada penelitian ini cara mengukur hasil belajar siswa menggunakan teknik tes. Tes yang digunakan adalah tes tertulis berbentuk pilihan ganda.

Berdasarkan hasil observasi awal di SD Negeri Semaken khususnya kelas V, diketahui bahwa guru mendominasi proses pembelajaran (teacher centered) saat pelajaran matematika. Dasar pertimbangan guru mendominasi pembelajaran karena, materi pelajaran terlalu banyak dan guru takut apabila semua materi 
pelajaran tidak dapat disampaikan pada siswa. Ketakutan guru berdampak pada proses pembelajaran yang hanya memberikan uraian materi pelajaran. Uraian materi pelajaran diberikan melalui ceramah. Sikap siswa hanya sebagai pendengar, pencatat, dan terkadang tampil di depan kelas untuk menuliskan jawaban atau memresentasikan hasil jawabannya. Oleh karena itu, proses pembelajaran oleh guru ditekankan pada penuntasan materi pelajaran yang ada pada kurikulum.

Permasalahan lain yang terjadi adalah tingkat kepercayaan diri siswa sangat rendah. Hal ini, dapat dilihat pada saat guru memberikan kesempatan siswa untuk tampil di depan kelas menuliskan, memresentasikan, atau menempelkan hasil jawaban siswa enggan, siswa tidak mau aktif di kelas karena siswa merasa malu dan selalu dihantui rasa cemas karena takut salah dalam mengerjakan soal matematika. Selain itu, pada setiap sesi pertanyaan yang dilakukan oleh guru pada materi yang belum jelas, semua siswa malu bertanya padahal mereka belum memahami materi. Menurut pengakuan salah satu siswa, hal tersebut karena siswa merasa takut pada saat mengikuti pelajaran matematika karena sudah tertanam pada pemikiran siswa bahwa matematika adalah pelajaran yang sulit untuk dipahami dan dikerjakan. Pengakuan tersebut juga dialami oleh siswa lain.

Menurut Fishbein \& Ajzen (Parsons, Croft \& Harrison, 2011, p.53), "self-confidence is belief", kepercayaan diri adalah sebuah keyakinan. Keyakinan menurut Scoenfeld (Hannula, Maijala \& Pehkonen, 2004, p.17) adalah pemahaman dan perasaan individu yang membentuk cara dan konsep individu terlibat dalam perilaku matematika. (Santrock, 2011, pp.361-363), hal ini berkaitan dengan pembentuk kepercayaan diri pada anak, bahwa penghargaan diri (self esteem) merujuk pada evaluasi global mengenai diri, sedangkan konsep diri (self concept) merujuk pada evaluasi mengenai bidang-bidang tertentu dari diri seperti penampilannya serta self efficacy adalah keyakinan bahwa "saya bisa", para siswa dengan self efficacy yang tinggi akan menggunakan pernyataan seperti "saya tahu bahwa saya akan mampu mempelajari materi pelajaran yang disampaikan di kelas ini" dan "saya berharap mampu menyelesaikan aktivitas ini dengan baik".

Faktor yang berpengaruh pada kepercayaan diri adalah faktor internal dan eksternal. Faktor internal merupakan gambaran mental tentang diri seseorang (self concept), sejauh mana seseorang punya keyakinan kemampuan diri (self efficacy) atau kemampuan diri seseorang dalam mengerjakan sesuatu hal atas kemampuannya sendiri tanpa bantuan orang lain, kesadaran akan harga diri seseorang (self esteem), dan keberhasilan seseorang dalam meraih cita-cita serta keinginan yang disertai dengan tekat yang kuat. Faktor eksternal meliputi (1) lingkungan keluarga, merupakan titik awal pembentukan kepribadian. (2) Pendidikan formal, merupakan tempat dimana rasa kepercayaan diri itu diterapkan dan dilatih kepada teman sebayanya. (3) Pendidikan nonformal, merupakan tempat pendukung dan penambah ilmu pada kegiatan ketrampilan dan ketangkasan yang digunakan sebagai pendukung membangun rasa kepercayaan diri. Oleh karena itu, aspek kepercayaan diri yang diambil dalam penelitian ini adalah (self concept) gambaran mental tentang diri seseorang, (self efficacy) keyakinan kemampuan diri, dan self esteem harga diri seseorang pada siswa dalam pendidikan formal.

Berdasarkan hasil wawancara peneliti dengan guru kelas $\mathrm{V}$, terungkap bahwa dalam proses pembelajaran, guru lebih sulit memberikan pemahaman konsep matematika dari pada mata pelajaran yang lain. Guru hanya menyampaikan rumus dan siswa mencatat rumus tersebut tanpa deberikan penjelasan, peragaan, langkah, atau asal mula mendapatkan rumus tersebut. Hal ini sangat menghambat transfer pembelajaran khususnya mata pelajaran matematika. Hal ini menyebabkan siswa hanya dapat memahami pelajaran tanpa mengetahui implementasi dalam kehidupan sehari-hari.

Usaha yang selama ini dilakukan guru dalam mengatasi rendahnya kepercayaan diri dan proses belajar adalah dengan menggunakan metode ceramah. Metode yang melibatkan guru secara aktif dalam poses pembelajaran dan siswa menerima materi yang diberikan guru tanpa memunyai inisiatif mencari dan menemukan sendiri pengetahuan dan ketrampilan yang mereka butuhkan. Selain itu, guru hanya memberikan tugas dan pekerjaan rumah pada siswa. Meskipun guru sudah menerapkan metode ceramah dan pemberian tugas, tetapi hasil yang didapatkan belum sesuai dengan yang diharapkan.

Guru belum mencoba metode pembelajaran yang mengaktifkan siswa atau (student centered). Penyebabnya selain mementingkan penuntasan materi yaitu guru belum mengetahui 
inovasi proses pembelajaran. Walaupun pada zaman modern saat ini banyak metode-metode pembelajaran yang mengaktifkan siswa. Pada kenyataaannya guru hanya monoton menggunakan satu metode pembelajaran. Metode yang diterapkan telah diyakini guru dapat memberikan hasil yang baik untuk siswa. Keyakinan tersebut tidak sesuai kenyataan yang terjadi di kelas V SDN Semaken.

Sehubungan dengan permasalahan tersebut di atas, maka upaya meningkatkan rasa kepercayaaan diri dan proses belajar pada siswa kelas V SD N Semaken Kecamatan Kalibawang Kabupaten Kulon Progo dalam pembelajaran Matematika merupakan suatu kebutuhan yang sangat mendesak untuk dilakukan. Salah satu inovasi pembelajaran matematika dengan pendekatan matematika realistik (PMR) sangat tepat dilaksanakan. Menurut Gravemeijer (1994, pp.91-93), dalam PMR ada lima tahapan yang harus dilalui siswa yaitu penyelesaian masalah, penalaran, komunikasi, kepercayaan diri dan representasi. Pada tahap penyelesaian masalah, siswa menyelesaikan masalah dan menemukan ide dengan cara sendiri. Pada tahap penalaran, siswa dilatih untuk bernalar dalam mengerjakan soal matematika. dalam tahap komunikasi, siswa dapat memberitahu jawaban yang dipilih pada temannya. Tahap kepercayaan diri, siswa diharapkan dapat melatih kepercayaan diri melalui penyampaian jawaban soal dan menyampaikannya ke depan kelas. Pada tahap representase, siswa mendapat kebebasan dalam memilih bentuk representasi yang diinginkan (benda konkrit atau lambang-lambang matematika). Pada penelitian ini dilaksanakan tindakan sesuai dengan karakteristik PMR. Tindakannya yaitu pemahaman masalah kontektual, mendiskripsikan dan menyeleseikan masalah kontektual, mendiskusikan jawaban dan penarikan kesimpulan. Melaui PMR siswa dapat belajar dengan menyenangkan melalui keterkaitan materi dengan kehidupan nyata. Selain itu, siswa memunyai kesempatan untuk mengasah intelektualnya di depan siswa lainnya dan guru. Melalui hal demikian siswa merasa dihargai kemampuannya.

Menurut Gravemeijer (1994, pp.90-91), terdapat tiga prinsip utama dalam PMR, yaitu: (a) guided reinvention and progressive mathematizing, Siswa menemukan sendiri suatu konsep, prinsip atau prosedur dengan melalui penyelesian masalah kontektual. dalam pemecahan masalah kontektual melalui proses matematisasi, siswa membangun sendiri pengetahu- an informalnya. oleh karena itu, masalah yang real atau masalah yang kontektual dianggap perlu dalam berbagai penyelesaian. selain itu, variasi strategi informal juga diperlukan. dari strategi tersebut, siswa dengan bimbingan guru melaksanakan generalisasi dan formalisasi, sampai siswa menemukan algoritma. proses di atas sampai penemuan algoritma disebut dengan proses matematisasi vertikal. pada penggunaan bahasa matematika dan ditemukannya algoritma, artinya bahwa siswa menemukan pengetahuan matematika formal, serta dapat digambarkan pada Gambar 1.

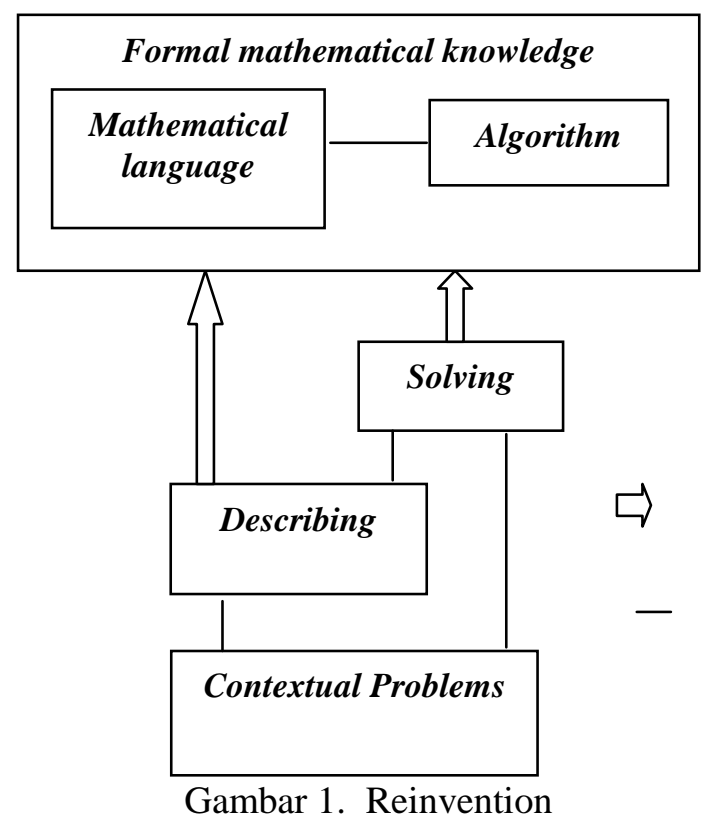

(b) didactical phenomenology, Merupakan suatu fenomenana dilihat dari masalah kontektual. Masalah kontektual tersebut diinvestigasi oleh siswa. Selain itu, siswa menggunakan analisis dari keidupan nyata sebagai sumber dari matematika. Fenomena dari kehidupan nyata berfungsi untuk memberikan kontribusi dalam matematika, artinya bahwa bagaimana siswa dapat menghubungkan fenomena nyata dan konsep yang muncul kepada siswa. Didactical phenomenology dalam PMR menekankan pada pentingnya masalah kontekstual. Masalah kontektual untuk memberikan topik matematika kepada siswa. Hal itu digunakan sebagai bahan pertimbangan kecocokan penggunaan masalah kontektual yang dipilih. Pemilihan masalah kontektual tersebut disajikan dengan melihat topik-topik matematika yang dipelajari dan konsep serta prosedur matematika. Konsep dan prosedur diupayakan penemuan sendiri oleh siswa bukan dari guru. (c) Self-developed models (model-model dibangun sendiri oleh sis- 
wa), Prinsip ini sebagai jembatan antara pengetahuan informal dengan formal siswa. Selanjutnya, siswa diberikan kebebasan untuk pengembangan model-modelnya sendiri. Pada awalnya, model ini merupakan model yang berasal dari hal yang nyata siswa dan merupakan situasi khusus, selanjutnya melalui generalisasi dan formalisasi model tersebut menjadi model penalaran matematika dan medel penalaran matematika merupakan pengetahuan formal bagi siswa. Aktivitas pengembangan model berupa membuat gambar, tabel, atau simbol informal. Dalam prinsip ini, peran guru sebagai fasilisator dan guru harus memunyai pemahaman tentang pemberian proses kontruksi pada pola pikir siswa. Tahapan ini dapat digambarkan melalui gambar berikut.

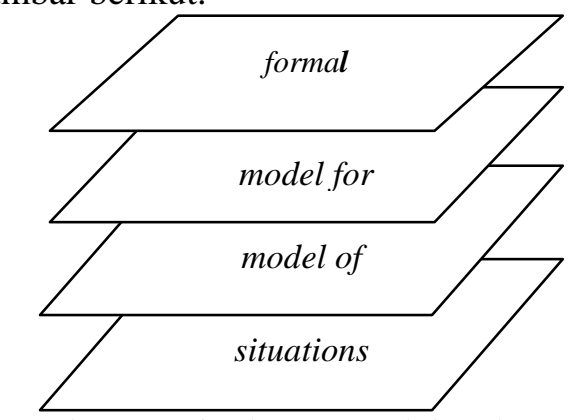

Gambar 2. Tingkatan Model Dalam PMR

(Gravemeijer, 1994, p.100)

Pada tingkatan yang pertama, berkaitan dengan aktivitas pada kehidupan nyata. Hal ini berkaitan dengan karakteristik RME pada penggunaan masalah kontektual dan nyata dialami siswa. Siswa menggunakan pengetahuan situasional dan menerapkannya dalam situasi masalah yang sedang dialami siswa. Tingkatan kedua tingkatan ini menjadi dasar untuk mengembangkan pengetahuan matematika formal dan masih kontektual. Tingkatan ketiga tingkatan ini, dari tahap ke-2 dan melalui proses generalisasi dan formalisasi, model of diarahkan ke model for, untuk mencapai pemikiran matematika pada tingkat yang formal. Tingkatan keempat, siswa diarahkan dan dibimbing untuk mencapai pengetahuan matematika formal. Hal ini, dapat berupa algoritma, prosedur konvensional, rumus dan lain sebagainya.

Van den Hauvel-Panhuizen (Anugrahana, 2010, pp.38-39), mendiskripsikan prinsipprinsip PMR. (1) Activity Principle, merupakan prinsip aktivitas yang menyatakan bahwa matematika adalah aktivitas manusia, yaitu matematika yang paling baik dipelajari dengan melakukannya. (2) Reality Principle, Merupakan prinsip realitas yang mana pembelajaran dimulai dari dunia nyata dan akan kembali ke dunia nyata lagi. (3) Level Principle, merupakan prinsip perjenjangan yang menyatakan bahwa pemahaman siswa dimulai dari beberapa jenjang. Mulai dari menemukan (to invent) penyelesaian masalah kontekstual secara informasi ke skematis, ke pemerolehan insight terus ke penyelesaian secara formal masalah matematika. (4) Interview Principle, merupakan prinsip jalinan yang menyatakan bahwa pembelajaran matematika adalah pembelajaran yang mengaitkan matematika dengan bidang lain. (5) Interaction principle. Merupakan prinsip interaksi yang menyatakan bahwa belajar matematika adalah aktivitas manusia yang juga dipandang sebagai aktivitas sosial. (6) Guidance principle, merupakan prinsip bimbingan dan menyatakan bahwa dalam menemukan kembali (re-invent) matematika, siswa masih membutuhkan bimbingan.

Dari paparan di atas dapat disimpulkan, PMR merupakan pembelajaran yang mengaktifkan aktivitas manusia dilihat dari prinsip dalam PMR yang menekankan pada penemuan sendiri oleh siswa melalui masalah kontektual dan sampai siswa dapat menyelesaikan matematika secara formal. Dalam pembelajaran menggunakan rme, mengkaitkan matematika dengan bidang yang lain dan semua prinsip ini siswa harus mendapatkan bimbingan dari guru karena pada dasarnya siswa masih membutuhkan bimbingan.

Menurut Streefland (1990, p.28) terdapat 5 prinsip belajar-mengajar dalam PMR di sekolah dasar, yaitu: (1) konstruksi yang distimulasi dengan kekonkretan. Benda-benda konkrit dimanipulasi oleh siswa dalam kerangka menunjang usaha siswa dalam proses matematisasi; (2) pengembangan alat matematika untuk membawa dari konkret ke abstrak. Belajar konsep dan ketrampilan dalam matematika merupakan proses yang panjang dengan melalui berbagai tingkatan keabstrakan sehingga diperlukan alat matematika; (3) penyetimulasian free production dan refleksi. Siswa, dengan arahan guru, mengontruksi dan menghasilkan matematika dengan cara dan bahasa mereka sendiri. Hasil aktivitas matematika siswa dalam mengonstruksi dilakukan juga melalui tahapan refleksi pada apa yang telah dihasilkannya. (4) Penyetimulasian aktivitas sosial pada interaksi belajar. (5) Pemaduan (Intertwining) antarpokok bahasan untuk mendapatkan struktur materi secara matematis. Setiap pokok bahasan tidak berdiri sendiri tetapi diintegrasikan de- 
ngan yang lain, misalnya memadukan perkalian dengan pengukuran. Prinsip dalam belajar dan mengajar PMR di atas sesuai dengan tujuan pembelajaran matematika dalam Permendiknas No 22 tahun 2006.

Permendiknas No. 22 Tahun 2006 tanggal 23 Mei 2006, tentang Standar Isi pada lampirannya menegaskan bahwa tujuan pembelajaran matematika adalah: (1) memahami konsep matematika, menjelaskan keterkaitan antarkonsep dan mengaplikasikan konsep atau algoritma, secara luwes, akurat, efisien, dan tepat, dalam pemecahan masalah; (2) menggunakan penalaran pada pola dan sifat, melakukan manipulasi matematika dalam membuat generalisasi, menyusun bukti, atau menjelaskan gagasan dan pernyataan matematika; (3) memecahkan masalah yang meliputi kemampuan memahami masalah, merancang model matematika, menyelesaikan model dan menafsirkan solusi yang diperoleh; (4) mengomunikasikan gagasan dengan simbol, tabel, diagram, atau media lain untuk memerjelas keadaan atau masalah; (5) memiliki sikap menghargai kegunaan matematika dalam kehidupan, yaitu memiliki rasa ingin tahu, perhatian, dan minat dalam memelajari matematika, serta sikap ulet dan percaya diri dalam pemecahan masalah (Depdiknas, 2006, p.417). Dari uraian ini tampak bahwa, pemecahan masalah merupakan salah satu kompetensi penting yang perlu dimiliki siswa dan pembelajaran hendaknya dimulai dengan pengenalan atau pengajuan masalah yang yang sesuai dengan situasi (contextual problem). Dengan pengajuan masalah kontektual, siswa secara bertahap dibimbing menguasai matematika. Apabila dicermati secara mendalam, tampak bahwa pembelajaran dengan pendekatan kontekstual ataupun PMR cocok atau mendukung apa yang telah diuraikan pada PP No. 19 dan Permendiknas di atas, terutama dengan tujuan pembelajaran matematika dan penekanan pembelajaran dengan pendekatan kontekstual.

Menurut Soedjadi (2001, p.2), pembelajaran matematika realistik pada dasarnya adalah pemanfaatan realitas dan lingkungan yang dipahami peserta didik untuk memperlancar proses pembelajaran matematika, sehingga mencapai tujuan pendidikan matematika secara lebih baik dari pada yang lalu. Realitas adalah hal-hal yang atau konkret yang dapat diamati atau dipahami peserta didik lewat membayangkan. Dengan kata lain masalahnya dapat berupa dunia tetapi ini tidak selalu perlu, masalah yang dimaksud dapat pula berupa aplikasi/penerapan atau pemodelan bahkan masalah formal matematika sejauh itu dalam pikiran siswa. Sedangkan yang dimaksud dengan lingkungan adalah lingkungan tempat peserta didik berada baik lingkungan sekolah, keluarga maupun masyarakat yang dapat dipahami peserta didik. Untuk itu, agar tujuan mata pelajaran tercapai dengan optimal, maka guru perlu merencanakan dengan sungguh-sungguh.

Hadi (Supinah, 2008, p.21) Konsepsi PMRI tentang aspek-aspek dalam pembelajaran Matematika: (1) Memulai pembelajaran dengan mengajukan masalah (soal) yang 'riil' bagi siswa sesuai dengan pengalaman dan tingkat pengetahuannya, sehingga siswa segera terlibat dalam pembelajaran secara bermakna. (2) Permasalahan yang diberikan tentu harus diarahkan sesuai dengan tujuan yang ingin dicapai dalam pembelajaran tersebut; (3) Siswa mengembangkan atau menciptakan model-model simbolik secara informal terhadap persoalan/permasalahan yang diajukan; (4) Pembelajaran berlangsung secara interaktif, siswa menjelaskan dan memberikan alasan terhadap jawaban yang diberikannya, memahami jawaban temannya (siswa lain), setuju terhadap jawaban temannya, menyatakan ketidaksetujuan, mencari alternatif penyelesaian yang lain, dan melakukan refleksi terhadap setiap langkah yang ditempuh atau terhadap hasil pembelajaran.

Pada pelaksanaannya PMR memberdayakan siswa pada hal-hal yang riil sesuai dengan yang dialaminya tersebut dalam kehidupan sehari-hari. Dengan pendekatan ini, siswa diajak mendalami matematika yang dihubungkan dengan kehidupannya sehari-hari. Oleh karena itu, proses pembelajarannya akan menyenangkan. Diharapakan, dengan pendekatan matematika realistik, siswa dapat meningkatkan pola pikirnya, daya kreatifitasnya, rasa kepercayaan dirinya dan hasil belajarnya. (Tandililing, 2003, p.3) Kelebihan pendekatan matematika realistik antara lain: (1) karena siswa membangun sendiri pengetahuannya maka siswa tidak mudah lupa dengan pengetahuannya; (2) suasana dalam proses pembelajaran menyenangkan karena menggunakan realitas kehidupan, sehingga siswa tidak cepat bosan belajar matematika; (3) siswa merasa dihargai dan semakin terbuka karena setiap jawaban siswa ada nilainya; (4) memupuk kerja sama dalam kelompok; (5) melatih keberanian siswa karena harus menjelaskan jawabannya; (6) melatih siswa untuk terbiasa berfikir dan mengemukakan pendapat; (7) pendidikan budi pekerti, 
misalnya saling kerja sama dan menghormati teman sedang berbicara. Kekurangan dari pendekatan matematika realistik yaitu (1) karena seudah terbiasa di beri informasi terlebih dahulu maka siswa masih kesulitan dalam menemukan sendiri jawabannya; (2) membutuhkan waktu yang lama terutama bagi siswa yang lemah; (3) siswa yang pandai kadang-kadang tidak sabar untuk menanti; (4) membutuhkan alat peraga yang sesuai dengan situasi pembelajaran saat itu. Untuk meminimalkan kekurangan dari PMR guru harus dapat mengembangkan kreatifitas dalam pembelajarannya seperti mengaitkan materi dengan kehidupan sehari-hari siswa.

Dari permasalahan di atas diperolah rumusan masalah Bagaimana meningkatkan kepercayaan diri dan proses belajar matematika siswa kelas V SD Negeri Semaken Kecamatan Kalibawang Kabupaten Kulon Progo tahun ajaran 2012/2013 melalui pendekatan matematika realistik? Tujuan penelitian adalah untuk meningkatkan kepercayaan diri dan proses belajar matematika melalui pendekatan matematika realistik pada siswa kelas V SD Negeri Semaken Kecamatan Kalibawang Kabupaten Kulon Progo tahun ajaran 2012/2013. Bagi siswa, adapun manfaat penelitian ini adalah siswa kelas V SD lebih termotivasi terhadap mata pelajaran matematika, siswa memiliki rasa percaya diri di kelas, dan siswa memiliki sikap positif terhadap pelajaran matematika. Guru mendapatkan umpan balik dan dasar memerbaiki proses pembelajaran, Guru menerapkan pendekatan matematika realistik dalam pembelajaran matematika di kelas. Sekolah mendapat masukan tentang pelaksanaan penelitian tindakan kelas, dan Meningkatkan kualitas pembelajaran di sekolah tersebut.

\section{Metode}

Jenis Penelitian dalam penelitian ini adalah penelitian tindakan kelas (classroom action research).

Waktu dan Tempat Penelitian

Tabel 1. Pelaksanaan Penelitian

\begin{tabular}{cccc}
\hline \multirow{3}{*}{ Siklus } & \multicolumn{3}{c}{ Pelaksanaan } \\
\cline { 2 - 4 } & $\begin{array}{c}\text { Pertemuan } \\
\text { I }\end{array}$ & $\begin{array}{c}\text { Pertemuan } \\
\text { II }\end{array}$ & $\begin{array}{c}\text { Pertemuan } \\
\text { III }\end{array}$ \\
\hline Siklus & Jumat, 17 & Senin, 20 & Rabu, 22 \\
I & Mei 2013 & Mei 2013 & Mei 2013 \\
Siklus & Senin, 27 & Rabu, 29 & Jumat, 31 \\
II & Mei 2013 & Mei 2013 & Mei 2013 \\
\hline
\end{tabular}

Tempat Penelitian ini di kelas V SD Negeri Semaken Kelurahan Banjararum Kecamatan Kalibawang Kabupaten Kulon Progo.

Target/Subjek Penelitian

Subjek Penelitian ini adalah semua siswa kelas V SD Negeri Semaken Kelurahan Banjararum Kecamatan Kalibawang Kabupaten Kulon Progo tahun ajaran 2012/2013 sebanyak 20 orang.

Prosedur tindakan yang diterapkan dalam penelitian tindakan kelas ini, mengacu pada empat aspek pokok model (Kemmis \& Taggart, 1988, p.11) yaitu perencanaan, pelaksanaan, observasi, dan refleksi. Adapun Keempat aspek model Kemmis dan Taggart melalui tahapan sebagai berikut:

Perencanaan penelitian tindakan siklus I. Pada tahap ini peneliti menentukan fokus peristiwa yang dianggap perlu untuk diamati secara mendalam. Selanjutnya merencanakan perencanaan meliputi: (a) Kelas penelitian adalah kelas V SD Negeri Semaken Kecamatan Kalibawang Kabupaten Kulon Progo. (b) Waktu penelitian adalah semester II, dimulai dari tanggal 17 Mei 2013 sampai dengan tanggal 3 Juni 2013. (b) Menyiapkan lembar observasi guru. Observasi guru dilaksanakan untuk melihat aktivitas guru dalam pelaksanaan pembelajaran menggunakan PMR. Dalam melihat aktivitas guru menggunakan pedoman observasi yang telah divalidasi oleh dosen pembimbing. (c) Menyiapkan instrumen wawancara kepercayaan diri siswa yang akan dilaksanakan pada setiap akhir tindakan. Dalam melihat kepercayaan diri siswa menggunakan pedoman wawancara tak terstruktur yang telah divalidasi oleh dosen pembimbing. (d) Menyiapkan lembar kerja siswa individu (LKSI), lembar kerja siswa kelompok (LKSK), benda nyata atau alat peraga yang dibutuhkan. LKSI/LKSK yang digunakan telah divalidasi oleh dosen validator. (e) Tes hasil belajar matematika siswa, soal tes yang digunakan telah diuji dan validasi oleh dosen validator. (f) Membuat jadwal penelitian bersama-sama dengan guru kelas V. (g) Menentukan indikator dalam penelitian ini yaitu Mengidentifikasi sifat-sifat bangun ruang dan Menentukan jaring-jaring berbagai bangun ruang sederhana. (h) Guru membentuk kelompok kecil yang terdiri 5 orang dari setiap kelompok dan mempertimbangkan perbedaan jenis kelamin dan kemampuan akademis siswa. Tindakan dalam penelitian ini dilakukan dalam dua siklus. Tahap pelaksanaan siklus I mengikuti ske- 
nario yang telah dirancang. Hal ini meliputi kegiatan awal, kegiatan inti, dan kegiatan penutup. Pada kegiatan tersebut mencakup langkahlangkah (sintaks) tindakan pembelajaran matematika menggunakan PMR. Adapun tindakan tiap pertemuan yaitu: (a) pemahaman masalah kontekstual; (b) mendeskripsikan dan menyelesaikan masalah kontekstual; (c) membandingkan dan mendiskusikan jawaban; dan (d) penarikan kesimpulan. Pada tahap observasi, dilaksanakan oleh peneliti dan kolaborator secara berkelanjutan saat pembelajaran berlangsung. Tahap ini dilaksanakan dalam waktu yang bersamaan dengan tahap pelaksanaan tindakan. Pada tahap ini mengamati proses pembelajaran menggunakan lembar observasi guru dan respon siswa. Pengamatan dilakukan oleh peneliti dibantu oleh kolaborator. Hal ini, agar guru dapat menjalankan proses pembelajaran menggunakan pendekatan PMR dengan maksimal. Wawancara pada siswa menggunakan pedoman wawancara tak terstruktur yang telah dipersiapkan sebelumnya. Wawancara dilaksanakan oleh observer pada saat selesai pelaksanaan tindakan. Tahap Refleksi pada penelitian ini dilaksanakan pada akhir siklus pertama. Tahap refleksi digunakan untuk mengevaluasi proses dan hasil tindakan oleh peneliti, guru dan observer. Hasil tindakan dianalisis untuk dilihat target pencapaiannya. Apabila pembelajaran yang telah dilaksanakan telah memenuhi kriteria keberhasilan maka tindakan dihentikan. Apabila tidak mencapai target yang diharapkan, maka dilaksanakan perbaikan untuk dilaksanakan pada siklus berikutnya.

Pada penelitian ini dilanjutkan pada Siklus II, Siklus ini dilaksanakan karena pembelajaran pada siklus I dinilai belum berhasil mencapai ketuntasan belajar dan proses belajar siswa. Langkah-langkah yang dilakukan dalam siklus II pada dasarnya sama dengan siklus I, akan tetapi pada siklus II dilakukan perbaikan terhadap kekuarangan pada siklus I. Jika pada siklus II hasil observasi dan refleksi menunjukkan peningkatan pelaksanaan pembelajaran yang tercermin dari kriteria ketercapaian maka penelitian dihentikan sampai pada siklus II dan tidak dilanjutkan pada siklus berikutnya.

\section{Teknik dan Instrumen Pengumpulan Data}

Teknik pengumpulan data yang digunakan dalam penelitian ini adalah dengan menggunakan teknik tes dan non-tes. Teknik tes digunakan untuk mengukur hasil belajar ranah kognitif serta teknik non-tes digunakan untuk mengukur ranah afektif dan psikomotorik.

Validitas yang digunakan dalam penelitian ini adalah validitas isi (content validity). Validitas isi instrumen mengacu pada sejauh mana item instrumen mencakup keseluruhan situasi yang ingin diukur. Menurut (Sudjana, 2010, p.13) agar memenuhi validitas isi, dapat pula dimintakan bantuan ahli bidang studi. Validitas isi instrumen tes hasil belajar dapat diketahui dari kesesuaian intrumen tes tersebut dengan standar kompetensi dan kompetensi dasar, sedangkan untuk lembar observasi guru dan wawancara siswa diketahui dari kesesuaian instrumen yang telah dikembangkan dengan kisi-kisinya. Penyusunannya berdasarkan arahan dari dosen pembimbing serta instrumen tersebut divalidasi oleh dosen ahli (expert judgement) pendekatan PMR yaitu Dr. Sugiman, M,Si. Setelah melalui tahap (expert judgement), semua instrumen direvisi mengikuti saran dan arahan dari dosen ahli tersebut.

Pada instrumen tes hasil belajar matematika diuji coba untuk mengetahui reliabilitas dan daya pembeda tiap butir soal instrumen secara keseluruhan. Uji butir pertama dilaksanakan pada hari Sabtu tanggal 11 Mei 2013 di SD Negeri Mejing dan uji butir kedua tanggal 13 Mei 2013 di SDN 1 Dekso.

Berikut penjelasan untuk masing-masing instrumen yang digunakan:

\section{Teknik Tes}

Tes diberikan pada siswa setelah pelaksanaan tindakan menggunakan PMR dalam pembelajaran. Tes bertujuan untuk mengetahui akibat dari proses belajar yang didominasi siswa selama proses tindakan penelitian. Tes yang digunakan adalah tes individual dan bentuknya pilihan ganda. Tes pilihan ganda terdiri dari 18 soal yang disusun sesuai materi pelajaran tiap akhir siklus. Tes dilaksanakan dua kali. Tes siklus I pada tanggal 24 Mei 2013 dan tes siklus II pada tanggal 3 juni 2013. Hasil tes dianalisis untuk mengetahui hasil belajar matematika siswa setelah penerapan pendekatan PMR. Hasil tes tersebut berupa nilai tes hasil belajar siswa, dilanjutkan menghitung nilai rata-rata kelas dan persentase ketuntasan individu tiap siklus. Siswa dikatakan mencapai ketuntasan klasikal apabila dalam kelas tersebut tercapai hasil belajar minimal $80 \%$ dari jumlah siswa. Siswa dikatakan telah mencapai ketuntasan belajar individu apabila nilai minimal yang diperoleh yakni 75 . 


\section{Teknik Non-tes}

Observasi dalam penelitian ini dengan cara melakukan pengamatan langsung dan pencatatan mengenai pelaksanaan pemberian proses pembelajaran di kelas. Pelaksanaan pemberian proses pembelajaran di kelas menggunakan pendekatan PMR oleh guru dan respon siswa. Observasi dilakukan dengan menggunakan lembar observasi yang telah disusun sebelumnya. Adapun hal-hal yang diobservasi dalam peneliti ini yaitu Aktivitas guru dalam kegiatan pemberian proses pembelajaran menggunakan pendekatan PMR.

Secara garis pemberian proses pembelajaran guru yang termuat dalam lembar observasi yaitu: (1) Keterlaksanaan kegiatan pendahuluan; (2) Keterlaksanaan kegiatan inti (a) Pemahaman masalah kontektual (melalui Penggunaan konteks dunia nyata sebagai langkah awal pembalajaran matematika). (b). Mendiskripsikan dan menyelesaikan masalah kontektual (melalui penggunaan media kontektual dengan menekankan penyelesaian matematika bangun ruang secara informal sebelum menggunakan cara formal). (c) Membandingkan dan mendiskusikan jawaban. (d) Menarik kesimpulan; (3) Keterlaksanaan kegiatan penutup

Dalam penelitian ini, wawancara digunakan untuk mengukur kepercayaan diri siswa dalam aspek self concept, self efficacy, dan selfesteem. Wawancara ini diperlukan untuk memeroleh suatu umpan balik dari proses pembelajaran yang sudah berlangsung, yang selanjutnya dijadikan sebagai dasar untuk menyusun tindakan dalam merencanakan pengelolaan pembelajaran pada tahap berikutnya. Observer mencatat dan menggali data melalui wawancara pada tiap-tiap siswa. Dalam satu kelompok terdapat satu observer. Satu kelompok terdiri dari lima siswa. Pelaksanaan wawancara sesuai dengan pedoman wawancara tak terstruktur yang telah dipersiapkan dan telah divalidasi oleh dosen pembimbing.

Teknik Analisis Data

Teknik analisis data pada penelitian ini adalah analisis diskripsif kualitatif, dalam hal ini yang dimaksud adalah instrumen wawancara. Analisis yang diperoleh dideskipsikan kemudian diambil kesimpulan. Selanjutnya menggunakan analisis diskriptif kuantitatif untuk instrumen observasi dan tes hasil belajar. Dari analisis yang diperoleh berupa angka diolah dan dihitung berdasarkan rumus yang telah ditetap- kan, kemudian hasil dari olahan dideskripsikan dan diambil kesimpulan.

Proses analisa data pada penelitian ini sesuai model Miles and Huberman (Sugiyono, 2006, pp.337-345), yaitu langkah-langkah analisis data terdiri dari tiga alur kegiatan secara bersamaan, antara lain: reduksi data, penyajian data, dan kesimpulan. Adapun penjelasannya sebagai berikut: (1) Reduksi data, yaitu proses penyeleksian, pemilihan, penyederhanaan, dan pengkategorian data yang diperoleh dari berbagai sumber di lapangan. Hal ini bertujuan untuk mempermudah pengorganisasian dan keperluan analisis data serta penarikan kesimpulan; (2) Penyajian data, dalam tahap ini dilakukan dengan mengumpulkan informasi yang diperoleh dari hasil reduksi; (3) Data yang telah disajikan dievaluasi dan disusun penafsirannya untuk menentukan tindakan selanjutnya. Hasil evaluasi dan penafsiran adalah (a) perbedaan antara perencanaan tindakan, (b) persepsi guru, peneliti, dan observer tentang hasil observasi guru, wawancara terhadap siswa, dan tes hasil belajar, (c) penentuan tindakan berikutnya, dan (d) permasalahan dan pemecahan masalah yang terjadi saat penelitian; (4) Penarikan kesimpulan, merupakan paparan akhir tentang tindakan dari penafsiran dan evaluasi penyajian data penelitian. Kesimpulan yang dipaparkan dalam penelitian ini dilihat dari hasil belajar pada penerapan pendekatan PMR pada materi mengidentifikasi sifat-sifat bangun ruang dan menentukan jaring-jaring berbagai bangun ruang sederhana dan kepecayaan diri siswa.

\section{Analisa Data}

Data kualitatif diambil dari hasil wawancara yang telah dilaksanakan. Wawancara dilaksanakan oleh observer. Observer mencatat dan menggali data melalui wawancara pada tiap-tiap siswa. Dalam satu kelompok terdapat satu observer. Satu kelompok terdiri dari lima siswa. Pelaksanaan wawancara sesuai dengan pedoman wawancara tak terstruktur yang telah dipersiapkan dan telah divalidasi oleh dosen pembimbing. Selanjutnya diolah menggunakan diskriptif kualitatif. Hasil wawancara didiskripsikan sesuai data yang diperoleh pada saat penelitian.

Data kuantitatif diambil dari tes hasil belajar dan observasi pemberian proses pembelajaran oleh guru menggunakan PMR. Dari observasi tiap pertemuan diperoleh perolehan skor pencapaian pemberian proses pembelajaran oleh guru. Dari tes hasil belajar dirata-rata 
untuk ditemukan keberhasilan individu dan klasikal sesuai dengan target yang ditetapkan. Data tersebut diolah menggunakan diskriptif kualitatif dan presentase. (a) Data tes hasil belajar. Tes dilaksanakan dua kali. Tes siklus I pada tanggal 24 Mei 2013 dan tes siklus II pada tanggal 3 Juni 2013. Hasil tes dianalisis untuk mengetahui hasil belajar matematika siswa setelah penerapan pendekatan PMR. Hasil tes tersebut berupa nilai tes hasil belajar siswa, dilanjutkan menghitung nilai rata-rata kelas dan persentase ketuntasan individu tiap siklus. Siswa dikatakan mencapai ketuntasan klasikal apabila dalam kelas tersebut tercapai hasil belajar minimal $80 \%$ dari jumlah siswa. Siswa dikatakan telah mencapai ketuntasan belajar individu apabila nilai minimal yang diperoleh yakni 75. Menurut (Sudjana, 2010, p.109) Untuk menghitung nilai rata-rata kelas menggunkan rumus:

$$
\bar{X}=\frac{\sum X}{N}
$$

Keterangan:

$$
\begin{array}{ll}
\bar{X} & =\text { nilai rata-rata } \\
\sum X & =\text { jumlah seluruh skor } \\
N & =\text { banyaknya subjek }
\end{array}
$$

(b) Data hasil observasi pemberian proses PMR Observasi dalam penelitian ini untuk mengetahui pemberian proses pembelajaran menggunakan PMR. Observasi dilaksanakan oleh peneliti dan kolaborator. Observasi dilaksanakan pada saat tahapan pelaksanaan penelitian. Pernyataan dalam pedoman observasi memunyai dua alternatif jawaban, yaitu YA atau TIDAK serta dipertegas melalui keterangan. Apabila dipilih jawaban YA maka mendapatkan skor 1 dan apabila TIDAK maka mendapatkan skor 0 , selanjutnya dihitung presentasenya menggunakan rumus menurut Widoyoko (2012, p.110) sebagai berikut:

$$
\text { Persentase Skor }(P)=\frac{\text { shor yang diperoleh }}{\text { shor maksimal }} \times 100 \%
$$

Indikator Keberhasilan

Untuk menentukan berhasil atau tidaknya penelitian dibutuhkan indikator keberhasilan. Indikator dalam penelitian ini meliputi penilaian kualitatif maupun kuantitatif. Adapun kriteria keberhasilan dijelaskan sebagai berikut: (a) Dari segi kepercayaan diri, dikatakan berhasil apabila minimal $80 \%$ siswa kelas V SDN Semaken telah memiliki self concept, self efficacy, dan self esteem tinggi yang termuat pada komponen penilaian dalam lembar wawanca- ra.(b) Dari segi proses belajar, minimal $80 \%$ siswa telah memiliki nilai di atas KKM yaitu 75. Hal ini sesuai dengan KKM yang diterapkan oleh SDN Semaken.

\section{Hasil Penelitian dan Pembahasan}

Dari penelitian yang telah dilaksanakan, diperoleh hasil penelitian tentang kepercayaan diri dan proses pembelajaran di SDN Semaken Kecamatan Kalibawang Kabupaten Kulon Progo, adapun hasil penelitian yang diperoleh antara lain:

\section{Peningkatan Proses Pembelajaran}

Proses pembelajaran selama siklus I dan II mengalami peningkatan, peningkatannya dijabarkan berikut ini: (a) Pada siklus I guru telah melaksanakan pembelajaran menggunakan PMR. Akan tetapi skenario pembelajaran belum sepenuhnya dilaksanakan. Terlihat sebagian besar siswa tidak aktif mengikuti pelajaran dan hanya sebagian kecil siswa aktif mengikuti pelajaran, selain itu saat disampaikan motivasi oleh guru, sebagian besar siswa masih berbicara sendiri dengan siswa lain. Terlihat sebagian besar siswa pasif dalam pembahasan PR. Pada siklus II Pelaksanaan pembelajaran sepenuhnya dilaksanakan. Pada lembar observasi guru pertemuan pertama, kedua, dan ketiga, telah dilaksanakan sesuai dengan sekenario proses pembelajaran. Terlihat sebagian besar siswa telah aktif dalam proses pembelajaran dan termotivasi saat melaksanakan proses pembelajaran. Selain itu, sebagian besar siswa aktif diskusi dalam pembahasan PR. Siswa senang belajar menggunakan benda nyata. Benda nyata yang digunakan sering dijumpai dalam kehidupan sehari-hari oleh karena itu, siswa telah mengetahui bentuknya dan bersemangat untuk menyelesaikan masalah menggunakan benda nyata. (b) Pada siklus I pada pertemuan pertama dan kedua, hanya siswa aktif yang bersedia menempelkan jawaban hasil diskusinya, siswa lain diam saja melihat ada perwakilan kelompok yang menempelkan jawabannya. Pada siklus II Sebagian besar siswa bersedia menempelkan jawaban LKSI/LKSK. Hal ini terlihat minimal 4 siswa dalam kelompok, bersedia menempelkan jawabannya. (c) Pada siklus I pertemuan pertama dan kedua, terlihat sebagaian besar siswa tidak berpartisipasi dalam membandingkan jawaban dan penyimpulan materi. Siswa hanya duduk mendengarkan dan mencatat kesimpulan dari hasil jawaban siswa yang menempelkan jawabannya. Pada siklus II Sebagian 
besar siswa aktif membandingkan jawaban, apabila terdapat perbedaan jawaban dengannya. Hal ini terlihat ketika tindakan mendiskusikan jawaban dan penarikan kesimpulan mengenai konsep matematika, sebagian besar siswa ikut memberikan pendapatnya mengenai konsep matematika yang sedang dibahas dan dicari penyelesaiannya dalam LKSI/LKSK. Keaktifan lain dalam proses pembelajaran, siswa bersedia bertanya dengan guru atau dengan siswa lain ketika terdapat hal yang kurang dipahami. (d) Pada siklus I pertemuan pertama pemantauan guru terhadap kegiatan diskusi kelompok siswa tidak menyeluruh, hanya ditujukan pada kelompok tertentu saja sehingga kelompok lain tidak terkontrol dengan baik, dan terdapat siswa yang bergurau, bermain benda nyata, dan pasif saat berdiskusi. Proses pembelajaran yang belum terlaksana di atas, guru telah melaksanakannya pada pertemuan yang ketiga. Akan tetapi pada siklus I guru belum merefleksi terhadap pembelajaran yang ditempuh dan menanyakan kejelasan siswa. Pada siklus II Pemantauan guru terhadap kegiatan diskusi kelompok siswa menyeluruh. Semua kelompok didorong aktif dalam berdiskusi dan menyampaikan pendapat. Guru mewajibkan pada semua siswa untuk berpendapat saat diskusi. Guru memberikan informasi pada siswa bahwa apabila akan mendapatkan nilai yang tinggi. (e) maka harus selalu aktif dalam diskusi. Dari dorongan guru tersebut terlihat sebagian besar siswa menemukan cara penyelesaian masalah nyata menggunakan cara sendiri serta sebagian besar siswa tidak mencontek pekerjaan siswa lain. Tidak terlihat siswa yang bergurau atau berbicara dengan teman lain saat proses pembelajaran berlangsung. Siswa selalu aktif dalam diskusi, berpendapat tentang gagasannya dalam pemecahan masalah dalam LKSI/LKSK. Guru telah memberikan penguatan melalui menyimpulkan. Saat dilaksanakan penyimpulan sebagian besar siswa berlomba-lomba menyampaikan pendapatnya untuk perolehan konsep matematika. Selanjutnya, pada pertemuan pertama guru belum melaksanakan refleksi, akan tetapi pada pertemuan kedua, dan ketiga guru telah memberikan refleksi tentang pembelajaran yang telah dilaksanakan. Oleh karena itu, dari hasil di atas proses pembelajaran menggunakan PMR telah terlaksana dengan baik. Sebagian besar siswa semakin reaktif terhadap tindakan yang diberikan guru, siswa mampu mengerjakan masalah matematika menggunakan benda nyata, siswa dapat memeroleh pengetahuannya sendiri me- lalui benda nyata dan masalah yang dipecahkan, siswa mampu membandingkan dan menyampaikan gagasannya apabila tidak sesuai dengan jawaban siswa, konsep matematika yang sebelumnya dianggap sulit, setelah penelitian dilaksanakan siswa mampu mendapatkan konsep matematika tersebut melalui apa yang telah didiskusikan.

Dari proses belajar yang sebelumnya didominasi guru dan menjadi didominasi siswa yang maksimal, diperoleh hasil belajar yang maksimal pula. Sebagian besar siswa mengalami peningkatan hasil belajarnya. Peningkatan hasil belajar siswa pada siklus I memiliki nilai minimum sebesar 62 dan nilai maksimum sebesar 92 dengan nilai rata-rata 80,05 dan simpangan baku 8,90, sedangkan hasil belajar siswa pada siklus II memiliki nilai minimum sebesar 76 dan nilai maksimum sebesar 94 dengan nilai rata-rata 83,15 dan simpangan baku 6,09. Dari hasil tersebut terjadi peningkatan nilai rata-rata pada siklus II sebesar 3,1 dari siklus I. Persentase ketuntasan hasil belajar siswa pada pembelajaran PMR dapat dilihat pada tabel berikut

Tabel 2. Analisis Hasil Belajar Siswa Siklus I dan II

\begin{tabular}{ccccc}
\hline \multirow{2}{*}{$\begin{array}{c}\text { Hasil } \\
\text { Belajar }\end{array}$} & \multicolumn{2}{c}{ Siklus 1 } & \multicolumn{2}{c}{ Siklus 2 } \\
\cline { 2 - 5 } & $\begin{array}{c}\text { Jumlah } \\
\text { siswa }\end{array}$ & Persentase & $\begin{array}{c}\text { Jumlah } \\
\text { siswa }\end{array}$ & Persentase \\
\hline $\begin{array}{c}\text { Memenuhi } \\
\text { KKM }\end{array}$ & 17 & $85 \%$ & 20 & $100 \%$ \\
$\begin{array}{c}\text { Belum } \\
\text { memenuhi } \\
\text { KKM }\end{array}$ & 3 & $15 \%$ & 0 & $0 \%$ \\
\hline
\end{tabular}

Berdasarkan hasil analisis ketuntasan belajar pada Tabel 2, diketahui bahwa pada siklus I sebanyak 17 siswa atau sebesar $85 \%$ telah memenuhi KKM dan 3 siswa atau sebesar $15 \%$ belum memenuhi KKM. Setelah dilakukan perbaikan proses belajar siswa pada siklus II, siswa yang memiliki nilai rendah (belum memenuhi KKM) mengalami peningkatan hasil belajarnya. Pada siklus II, jumlah siswa yang memenuhi KKM sebanyak 20 siswa atau 100\%. 


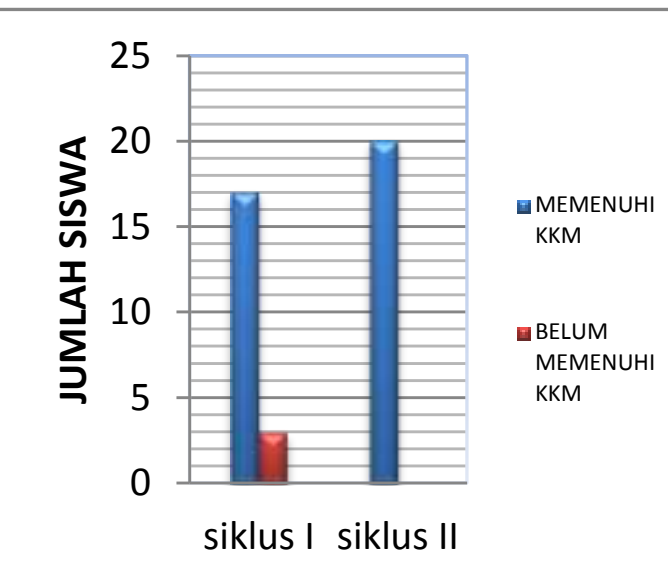

Gambar 3. Grafik Peningkatan Hasil Belajar Siswa

Hal ini sesuai dengan pendapat Gravemeijer dan De Lange (Hadi, 2002, p.4), yaitu: (a) Students should be given the opportunity of reinvent mathematics under the guidance of an adult, (b) The reinvention of mathematics ideas and concepts should start from exposure to a veriety of 'real world' problems and situations. Dengan demikian selama proses pembelajaran PMR berlangsung, terjadi interaksi antarguru dengan siswa dan siswa dengan siswa. Tahapan 2) mendiskripsikan dan menyelesaikan masalah kontektual, dalam hal ini, siswa diajak oleh guru untuk menemukan sendiri pengetahuannya yang berkaitan dengan konsep atau prinsip matematika. Sesuai dengan materi yang dipelajari dan masalah kontektual, serta siswa diberikan kebebasan berekplorasi menggunakan idenya sendiri. Pendapat lain menurut (Sudjana, 2010, p.56), Hasil belajar yang dicapai siswa melalui proses belajar-mengajar yang optimal cenderung menunjukkan hasil yang berciri: menambah keyakinan akan kemampuan dirinya. Artinya, ia tahu kemampuan dirinya dan percaya bahwa ia punya potensi yang tidak kalah dengan orang lain apabila ia berusaha sebagaimana harusnya.

\section{Peningkatan Kepercayaan Diri Siswa}

Sebelum pelaksanaan proses pembelajaran menggunakan PMR siswa memunyai tingkat kepercayaan diri yang rendah. Hal ini dapat dilihat saat guru memberikan kesempatan siswa untuk tampil di depan kelas menuliskan hasil jawaban hanya 3 siswa dari 20 siswa yang bersedia (self-concept). sebagian besar siswa atau 17 siswa tidak mau aktif di kelas karena siswa merasa malu dan selalu dihantui rasa cemas karena takut salah dalam mengerjakan soal matematika (self-concept). Pada sesi per- tanyaan yang dilakukan oleh guru pada materi yang belum jelas, 17 siswa malu bertanya (selfesteem). Hal tersebut karena, sebagian besar siswa merasa takut pada saat mengikuti pelajaran matematika karena sudah tertanam pada pemikiran siswa bahwa matematika adalah pelajaran yang sulit untuk dipahami dan dikerjakan (selfefficacy). Oleh karena itu, dilaksanakan PMR untuk meningkatkan kepercayaan diri siswa. Adapun peningkatan kepercayaan diri siswa selama siklus I dan II menunjukkan hal-hal sebagai berikut pada Tabel 3 .

Tabel 3. Peningkatan Kepercayaan Diri Siswa Siklus I dan siklus II

\begin{tabular}{ccc}
\hline \multirow{2}{*}{ Pertemuan } & \multicolumn{2}{c}{ Kepercayaan diri } \\
\cline { 2 - 3 } & Siklus I & Siklus II \\
\hline I & 6 siswa & 16 siswa \\
II & 9 siswa & 18 siswa \\
III & 14 siswa & 18 siswa \\
Jumlah & 29 siswa & 52 siswa \\
\hline
\end{tabular}

Adapun Grafik peningkatan kepercayaan diri siswa dalam pembelajaran disajikan pada gambar berikut ini:

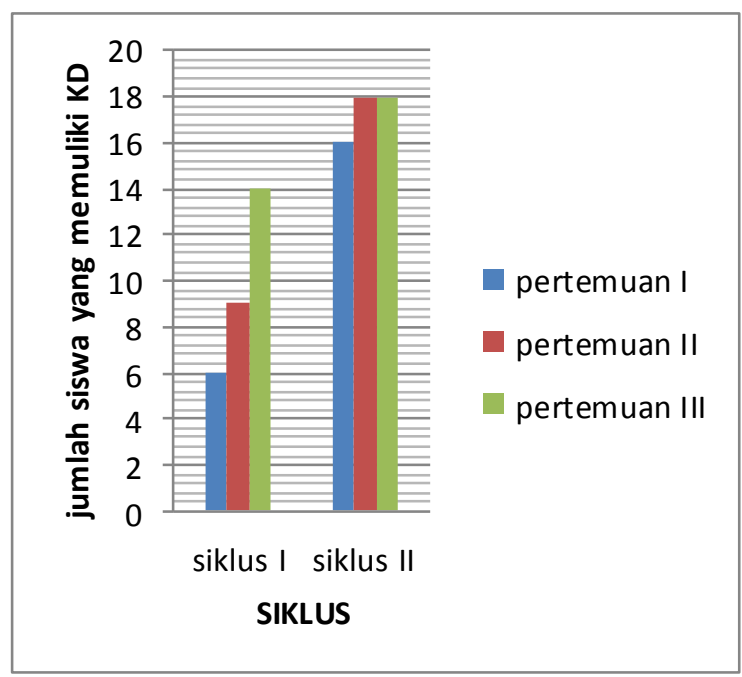

Gambar 4. Peningkatan Kepercayaan Diri Siswa

Secara umum, hasil analisis kepercayaan diri siswa siklus I, pertemuan 1 sebesar 6 siswa atau $30 \%$ dari 20 siswa yang memunyai tingkat kepercayaan diri, pertemuan II sebesar 9 siswa atau $45 \%$ dari 20 siswa yang memunyai tingkat kepercayaan diri, pertemuan III sebesar 14 siswa atau $70 \%$ dari 20 siswa yang memunyai tingkat kepercayaan diri. Hasil ini menunjukkan bahwa tingkat kepercayaan diri siswa 
mengalami peningkatan di setiap pertemuan pada siklus 1 .

Secara umum, hasil analisis kepercayaan diri siswa siklus II mengalami peningkatan. Hasil analisis kepercayaan diri siswa siklus II, pertemuan I sebanyak 16 siswa atau $80 \%$ dari 20 siswa yang memunyai kepercayaan diri, pertemuan II sebesar 18 siswa atau $90 \%$ dari 20 siswa yang memunyai tingkat kepercayaan diri, pertemuan III sebesar 18 siswa atau $90 \%$ dari 20 siswa yang memunyai tingkat kepercayaan diri. Hasil ini menunjukkan bahwa kepercayaan diri siswa mengalami peningkatan di setiap siklus. Variabel kepercayaan diri telah mencapai kriteria keberhasilan yang ditetapkan. Kriteria keberhasilan apabila 16 siswa atau sebesar 80\% dari 20 siswa memiliki kepercayaan diri, hal ini dilihat dari hasil wawancara.

Secara langsung proses pembelajaran PMR mendorong self esteem dan self eficacy yang tinggi. Pada penelitian ini dapat dilihat hasilnya bahwa, sebagian besar siswa semakin aktif berdiskusi karena siswa merasa lebih mudah untuk bersosilisasi dengan siswa lain, optimis dengan kemampuannya, dan menerima masukan dari teman untuk memerbaiki diri sendiri, berlatih dalam menyampaikan pendapat, dan semakin kompak dengan siswa lain, menyampaikan pendapat pada guru pada pembelajaran dikarenakan siswa bersikap positif dalam menyikapi kebenaran jawaban (self esteem), hal ini sesuai karakteristik individu yang memiliki self esteem yang tinggi oleh Rosenberg dan Owens (Guindon, 2010, p.68). Selain pendapat tersebut, menurut Preston (2007, p.18): Self-worth: the velue you place on your salf-how comfortable you are being you and this extent to which you feel worhty of happiness and succes. Competence: your beliefs about your capacity to achieve, solve problem and think your self. Belonging: wether you feel accepted and respected by others. Selfworth: the value you place on yourself-how comfor-table you are being you and the extent. Intinya adalah keyakinan dibentuk oleh harga diri. Harga diri artinya merupakan diri sendiri sejauh mana diri kita layak untuk bahagia atau sukses, kompetisi. Dapat dilihat bahwa semakin banyak siswa yang aktif menempelkan jawaban pada papan tulis karena yakin benar dengan jawaban LKSI/LKSK (self concept), kenyataan ini sesuai dengan pendapat Scoenfeld (Hannula, Maijala \& Pehkonen, 2004, p.17) bahwa pemahaman dan perasaan individu yang membentuk cara dan konsep individu terlibat dalam perilaku matematika. Senada dengan pendapat tersebut, menurut Santrock (2011, pp.361-363), para siswa dengan Self-efficacy yang tinggi akan menggunakan pernyataan seperti "saya tahu bahwa saya akan mampu memelajari materi pelajaran yang disampaikan di kelas ini" dan "saya berharap mampu menyeleseikan aktivitas ini dengan baik.

\section{Simpulan dan Saran}

Simpulan

Berdasarkan hasil analisis dan pembahasan penelitian dapat disimpulkan bahwa proses pembelajaran menggunakan PMR dapat meningkatkan kepercayaan diri dan proses belajar siswa kelas V SD N Semaken. Peningkatan tersebut diperoleh melalui tindakan PMR. Tindakan yang dilaksanakan adalah (a) pemahaman masalah kontekstual, (b) mendeskripsikan dan menyelesaikan masalah kontekstual, (c) membandingkan dan mendiskusikan jawaban, dan (d) penarikan kesimpulan.

Dampak dari peningkatan tersebut tercermin pada hasil belajar siswa. Hal ini dibuktikan pada siklus I sebanyak 17 siswa atau sebesar $85 \%$ telah memenuhi KKM dan 3 siswa atau sebesar $15 \%$ belum memenuhi KKM. Setelah dilakukan perbaikan proses belajar dan lebih didominasi siswa, hasil belajar siswa pada siklus II meningkat. Pada siklus II, jumlah siswa yang memenuhi KKM sebanyak 20 siswa atau $100 \%$.

\section{Saran}

Mencermati hasil penelitian yang ditemukan, maka saran disampaikan kepada beberapa pihak berikut. (1) Siswa: kepercayaan diri dan hasil belajar matematika sudah meningkat. Oleh karena itu perlu dipertahankan untuk peningkatan kualitas siswa. (2) Guru: serangkaian proses pembelajaran PMR dijadikan referensi dan diterapkan akan tetapi disesuaikan dengan kecocokan materi, selain itu untuk pengembangan diri dalam perbaikan proses pembelajaran. (3) Sekolah: PMR diterapkan pada semua kelas dengan dipertimbangkan kecocokan materi.

\section{Daftar Pustaka}

Anugrahana, Andri. (2010). Pengaruh pembelajaran matematika dengan menggunakan pendekatan realistik terhadap aktivitas siswa dan hasil belajar siswa di sekolah dasar. Tesis. Yogyakarta: Universitas Negeri Yogyakarta. 
Tandililing, Edy. (2003). Implementasi mathematic realistik education (RME) di sekolah. Artikel. Diambil pada tanggal 13 Oktober 2012, dari http://jurnal.untan.ac.id/index.php/jgm $\mathrm{m} /$ article/download/208/202

Depdiknas.(2003). Undang-Undang RI Nomor 20, Tahun 2003, tentang sistem pendidikan nasional.

Gravemeijer, K. (1994). Developing realistic mathematics education. Utrecht: Freudenthal Institute.

Guindon, M.H. (2010). Self esteem across the lifespan. New York: Routledge Taylor \& Francis Group.

Hadi, Sutarto. (2002). Effective teacher profesional development for implementation of realistik mathematics education in indonesia. Disertasi. Enschede:print partnersips kamp

Hanula, S.M., Maijala,H., and Pehkonen,E. (2004). Development of understanding and self-confidencein mathematics; grades 5-8 dalam The 28th International Conference of the International Group for the Psychology of Mathematics Education Volume 3 14-18 July 2004.

Kemmis \& Mc. Taggart. (1988). The action research planner. victoria: Deakin University.

Ibrahim. (2012). Pembelajaran matematika teori dan aplikasinya. Yoryakarta: SUKAPress UIN Sunan Kalijaga

Yamin, Martinis (2007). Kiat mengaktifkan siswa. Jakarta: Gaung Persada Pers

Sudjana, Nana.(2010). Penilaian hasil proses belajar mengajar. Bandung: PT Remaja Rosdakarya.
Hamalik, Oemar. (2005). Proses Belajar Mengajar. Jakarta: Bumi Aksara

Parson, S.,Croft, T., and Harisson, M.(2011). Engineering students' self confidence in mathematics mapped onto Bandura's self-efficacy, journal engineering education vol.6 issue 12011

Preston, D. L. (2007). 365 Steps to self- confidence. United Kingdom: Spring Hill House, Spring Hill Road Begbroke, Oxford OX5 1RX, available at bookfi.org.

Santrock. (2011). Life span development, 4th Edition. (Terjemahan Benedictine Widyasinta dan Novietha I. Sallama). New York: McGraw Hill Companies, Inc.

Streefland, L. (1990). Realistic mathematics education (RME). What does it mean? dalam contexts free productions tests and geometry in realistic mathemtics education. Editor Gravemeijer, K. dkk. Utrecht: OW \& OC

Supinah. (2008). Pembelajaran matematika SD dengan pendekatan kontektual dalam melaksanakan KTSP. Yogyakarta: P4TK Matematika

Uno, Hamzah. B. (2009). Model pembelajaran (menciptakan proses belajar mengajar yang kreatif dan efektif). Jakarta: Bumi Aksara.

Widoyoko, E.P. (2011). Teknik penyusunan instrumen pendidikan. Yogyakarta: pustaka pelajar.

Zulkardi. (2002). Developing a "rich" learning environment on realistic mathematics education (RME) ror students teachers in indonesia. Jurnal: FMIPA Unsri. 